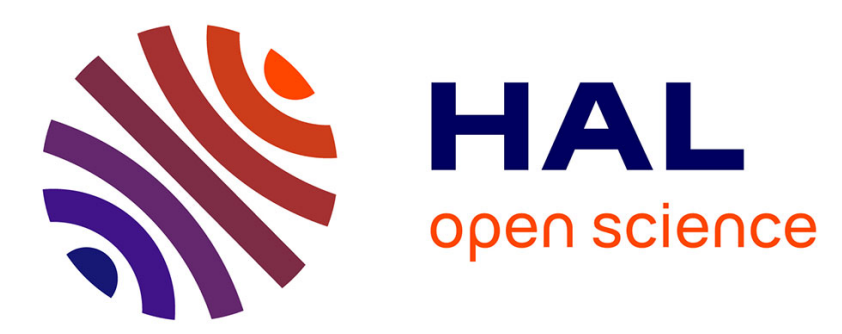

\title{
A stable fish reporter cell line to study estrogen receptor transactivation by environmental (xeno)estrogens.
}

\author{
A. Cosnefroy, F. Brion, B. Guillet, N. Laville, J. M. Porcher, P. Balaguer, S.
} Aït-Aïssa

\section{- To cite this version:}

A. Cosnefroy, F. Brion, B. Guillet, N. Laville, J. M. Porcher, et al.. A stable fish reporter cell line to study estrogen receptor transactivation by environmental (xeno)estrogens.. Toxicology in Vitro, 2009, 23 (8), pp.1450-4. 10.1016/j.tiv.2009.07.003 . hal-00453656

\section{HAL Id: hal-00453656 https://hal.science/hal-00453656}

Submitted on 5 Feb 2010

HAL is a multi-disciplinary open access archive for the deposit and dissemination of scientific research documents, whether they are published or not. The documents may come from teaching and research institutions in France or abroad, or from public or private research centers.
L'archive ouverte pluridisciplinaire HAL, est destinée au dépôt et à la diffusion de documents scientifiques de niveau recherche, publiés ou non, émanant des établissements d'enseignement et de recherche français ou étrangers, des laboratoires publics ou privés. 
1 A stable fish reporter cell line to study estrogen receptor transactivation by environmental

2 (xeno)estrogens

3 A. Cosnefroy ${ }^{1}$, F. Brion ${ }^{1}$, B. Guillet ${ }^{1}$, N. Laville ${ }^{1}$, JM. Porcher ${ }^{1}$, P. Balaguer ${ }^{2}$ and S. Aït-Aïssa ${ }^{1}{ }^{*}$

$4{ }^{1}$ INERIS, Unité d'Ecotoxicologie, BP2, f-60550 Verneuil-en-Halatte, France; ${ }^{2}$ INSERM U 896,

$5 \quad$ Institut de Recherche en Cancérologie de Montpellier, f-34298 Montpellier, France.

6 *Corresponding autor. Email: selim.ait-aissa@ineris.fr, Fax: +33 344556605.

8 Abstract : Cross-species differences between human and fish estrogen receptor (ER) binding by

9 environmental chemicals have been reported. To study ER transactivation in a fish cellular

10 context, we stably co-transfected the PLHC-1 fish hepatoma cell line with a rainbow trout

11 estrogen receptor (rtER) and the luciferase reporter gene driven by an estrogen response element

12 (ERE). This new cell model, called PELN-rtER (for $\underline{P} L H C-1-\underline{E R E-L u c i f e r a s e-N e o m y c i n), ~}$

13 responded to $17 \beta$-estradiol (E2) in a both concentration- and temperature-dependent manner, as

14 well as to environmental ER ligands from different chemical classes: natural and synthetic

15 estrogens, zearalenone metabolites, genistein, alkyphenoles and benzophenone derivatives. The

16 comparison with other in vitro models, i.e. human reporter cell lines (HELN-rtER, MELN) and

17 vitellogenin induction in primary cultures of rainbow trout hepatocytes, showed an overall higher

18 sensitivity of the human cells for a majority of ligands, except for benzophenone derivatives

19 which were active at similar or lower concentrations in fish cells, suggesting species-specificity

20 for these substances. Correlation analyses suggest that the fish cell line is closer to the trout

21 hepatocyte than to the human cell context, and could serve as a relevant mechanistic tool to study

22 ER activation in fish hepatic cellular context. 


\section{Introduction}

25 The widespread presence of endocrine disrupter compounds (EDCs) in the aquatic environment

26 has become a very important issue of environmental concern over the past few decades, as these

27 natural or man-made chemicals may cause adverse effects on wildlife (Sumpter, 2005). Given

28 the complexity of the endocrine system as well as the diversity of chemicals and their modes of

29 action, tiered approaches have been proposed for the screening (Tier 1) and testing (Tier 2) of

30 EDCs (reviewed by Hotchkiss et al., 2008). Tier 1 includes both in vitro and short term in vivo

31 assays. In this context, the evaluation of non mammalian in vitro screening assays has been

32 clearly identified as an important need to be addressed in EDC testing strategies (Hotchkiss et

33 al., 2008). However, compared to mammalian species, fewer non mammalian in vitro screening

34 assays have been developed. The lack of species specific screening assay may represent an

35 important gap in risk assessment of EDCs for aquatic organisms, and for fish in particular, since

36 cross-species differences have been identified with regard to the molecular mode of hormone

37 action (i.e. receptor binding affinities) or xenobiotic metabolism (Matthews et al., 2000; Wilson

38 et al., 2007; Hotchkiss et al., 2008).

39 One important mechanism in EDC action is mediated by the modulation of estrogen receptor

40 (ER) activation. Different assays exist to assess estrogenic activity of chemicals in fish. Among

41 them, the most widely used is based on vitellogenin (VTG) induction in isolated fish hepatocytes

42 (e.g. Pelissero et al., 1993, Smeet et al., 1999). Such in vitro assay is toxicologically relevant

43 because it measures natural gene response in cultured cells derived from a main target organ of

44 EDC (i.e. liver) and because it retains metabolic properties close to the in vivo situation.

45 However, it has also some limitations for screening purpose since it is relatively time-consuming

46 and may be the subject of inter-assay variability (reviewed by Navas and Segner, 2006). On the 
47 other hand, the use of receptor mediated expression of stable reporter gene system using

48 established cell lines serves as rapid, reproducible and specific assay. However to our

49 knowledge, only few stable reporter gene assays using fish cell lines have been described

50 (Ackermann et al., 2002), and none in hepatic cell context.

51 In this study, we describe the development of a new stable reporter gene assay for the assessment

52 of ER activation by chemicals in fish cellular context, by using the PLHC-1 hepatoma fish cell

53 line (Ryan and Hightower, 1994). In this model, kinetics of luciferase transactivation by estradiol

54 as function of exposure duration and temperature were determined, as well as its activation by

55 various ER ligands representative of different chemical classes. Finally, the comparison of this

56 new in vitro model with other well established assays for estrogenicity assessment, namely VTG

57 induction in isolated rainbow trout hepatocytes and human reporter cell lines derived from HeLa

58 (HELN-rtER) and MCF-7 (MELN) cells, highlighted some response specificity, possibly linked

59 to the fish receptor and/or fish cell context.

60 Materials and methods

61 Chemicals, materials and reagents

62 17 $\beta$-estradiol (E2, CAS\#50-28-2), 17 $\alpha$-Ethinylestradiol (EE2, CAS\#57-63-6), Estrone (E1,

63 CAS\#53-16-7), Estriol (E3, CAS\#50-27-1), 2,4-dihydroxybenzophenone (BP1, CAS\#131-56-6),

64 2,2',4,4'-tetrahydroxybenzophenone (BP2, CAS\#131-55-5), 2-hydroxy-4-methoxybenzophenone

65 (BP3, CAS\#131-57-7), 2,4,4'-trihydroxybenzophenone (THB, CAS\#1470-79-7),

66 diethylstilbestrol (DES, CAS\#56-53-1), Hexestrol (Hex, CAS\#84-16-2), genistein (Gen,

67 CAS\#446-72-0), 4-tert-octylphenol (4OP, CAS\#140-66-9), 4-nonylphenol (4NP, CAS\#54181-

68 64-5), bisphenol A (BPA, CAS\#80-05-7), $\alpha$-zearalenol ( $\alpha$-ZEE, CAS\#36455-72-8), $\beta$-zearalenol

69 ( $\beta$-ZEE, CAS\#71030-11-0) and $\alpha$-zearalanol ( $\alpha$-ZEA, CAS\#26538-44-3) were purchased from 
70 Sigma-Aldrich (France). All compounds were of purity higher than $98 \%$. Stock solutions of

71 chemicals were prepared in dimethyl sulfoxide (DMSO) at $10 \mathrm{mM}$ and stored at $-20^{\circ} \mathrm{C}$. Fresh

72 dilutions of test chemicals were prepared before each experiment. Culture medium and additives

73 were purchased from Gibco (France), fetal calf serum (FCS) and D-luciferin from Sigma-Aldrich

74 (Quentin Fallavier, France). Cell culture plastics were obtained from BD Bioscience (France),

75 except 96-well plates which were purchased from Greiner (France).

76 Plasmids

77 The construction of ERE- $\beta$ Glob-Luc-SVNeo and $\mathrm{pSG}_{5}$-rtER -puro $_{\text {- }}$ plasmids that encode 78 respectively for the luciferase reporter gene and the rainbow trout estrogen receptor short form $79(\mathrm{rtER} \alpha)$, has been described previously by Balaguer et al. (1999) and Molina-Molina et al. 80 (2008), respectively.

81 PLHC-1 cell line: culture conditions and stable transfection

82 The PLHC-1 cell line, obtained from the American Type Culture Collection (ATCC CRL 2406),

83 is derived from the hepatocellular carcinoma of the topminnow Poeciliopsis lucida (Ryan and

84 Hightower, 1994). PLHC-1 cells were routinely cultured at $30^{\circ} \mathrm{C}$ in minimum essential medium

85 with Earle's salts (E-MEM) supplemented with $10 \% \mathrm{v} / \mathrm{v}$ decomplemented fetal calf serum

86 (FCS), $1 \% \mathrm{v} / \mathrm{v}$ non-essential amino acids, $1 \% \mathrm{v} / \mathrm{v}$ of sodium pyruvate, $50 \mathrm{U} / \mathrm{ml}$ of penicillin and

87 streptomycin antibiotics in a 5\% $\mathrm{CO} 2$ humidified atmosphere. For stable transfection

88 experiments, PLHC-1 cells were plated onto $100 \mathrm{~mm}$ diameter Petri dishes in complete E-MEM

89 without antibiotics. Twenty four hours after plating, confluent cells were co-transfected with the

90 two plasmids described above by using the Lipofectamine $2000^{\mathrm{TM}}$ reagent (Gibco, France),

91 according to the manufacturer's instructions. After three hours, transfection reagent was removed

92 and cells were allowed to recover for 24 hours before addition of $3 \mathrm{mg} / \mathrm{ml} \mathrm{G} 418$ and $0.5 \mu \mathrm{g} / \mathrm{ml}$ 
93 puromycin as selecting agents. Medium was renewed every two days during one month before

94 first clones were isolated and amplified. Only few resistant clones (about forty clones in three

95 transfection dishes) were developed on the plates after one month of selection treatment with

96 antibiotics. Nevertheless twenty clones could be isolated and tested for luciferase induction by

97 E2. Among them, the clone 1.1 showed the highest induction of luciferase activity by E2. This

98 clone was chosen for further experiments and called PELN-rtER for PLHC-1 ERE-Luciferase

99 Neomycin-rtER.

$100 \quad$ Luciferase induction assay

101 PELN-rtER cells were seeded on 96 well plates (50000 cells per well) in phenol red free 102 medium supplemented with $3 \%$ dextran-coated charcoal treated FCS to remove serum steroids 103 (DCC medium) and left to incubate for $24 \mathrm{~h}$ before chemical exposure. This medium was used to 104 avoid interference due to estrogenic activity of phenol red and serum steroids in the assay. 105 Solvent (DMSO) content did not exceed $0.1 \% \mathrm{v} / \mathrm{v}$ in the culture medium. Cells were exposed to 106 test chemicals for 48 hours at $25^{\circ} \mathrm{C}$. Luciferase activity was then determined in living cells as 107 follows. The culture medium was removed and replaced by $50 \mu 1$ of D-luciferin $0.3 \mathrm{mM}$ in DCC 108 medium. After 5 min allowing a stabilisation of the luminescent signal, luminescence counts 109 were determined in a microplate luminometer ( $\mu$ Beta, Wallac). Results were expressed as 110 percentage of maximal luciferase induced by E2, the reference ligand.

111 Vitellogenin assay in primary culture of rainbow trout hepatocytes (PRTH)

112 Adult male rainbow trout (Onchorynchus mykiss) were obtained from a local hatchery (INRA, 113 Gournay-sur-Aronde, France). Fish were kept in tanks with aerated charcoal filtered tap-water at 114 a temperature of $15{ }^{\circ} \mathrm{C}$. Rainbow trout were fed with commercial fish food and acclimatized to 115 laboratory conditions for a minimum of 2 weeks before use in the experiments. Hepatocytes 
116 were isolated as previously described (Laville et al., 2004) and seeded in 96 well Primaria ${ }^{\mathrm{TM}}$ 117 microplates at a density of $5 \times 10^{5}$ cells per well and cultured at $15{ }^{\circ} \mathrm{C}$ in phenol red free

118 Leibovitz-15 medium (L-15) supplemented with 5\% DCC serum, penicillin and streptomycin (50

$119 \mathrm{U} / \mathrm{mL}$ each) and $10 \mathrm{mM}$ HEPES. Cells were left to incubate for $24 \mathrm{~h}$ before exposure to

120 chemicals for 96 hours. Solvent content (DMSO) did not exceed $0.1 \% \mathrm{v} / \mathrm{v}$ in the culture medium

121 and half of the medium was renewed after two days with fresh medium containing the test

122 chemical at the desired concentration. VTG quantification in extracellular culture medium was

123 performed using a competitive enzyme-linked immunosorbent assay (ELISA) according to the

124 method of Brion et al. (2002), using the AA-1 anti-salmon vitellogenin polyclonal antibodies

125 (Biosense, Norway) and home-made standard VTG purified from E2-induced male rainbow trout

126 (Brion et al., 2002).

127 Data analysis

128 A range of concentrations of chemical $(0.01 \mathrm{nM}$ to $1 \mu \mathrm{M}$ for estrogens and zearalenone 129 metabolites and $1 \mathrm{nM}$ to $10 \mu \mathrm{M}$ for the other chemicals) were tested in triplicate in each

130 independent experiment. Data were expressed as mean value of relative luminescence units 131 (RLU) \pm standard deviation (SD). Dose-response curves were modeled by using the Regtox 7.5

132 Microsoft Excel ${ }^{\mathrm{TM}}$ macro (available at http://eric.vindimian.9online.fr/), which uses the Hill 133 equation model and allows calculation of $\mathrm{EC}_{50}$. Relative estrogenic potencies (REP) were 134 determined as the ratio of $17 \beta$-estradiol $\mathrm{EC}_{50}$ to $\mathrm{EC}_{50}$ of the test chemical.

\section{$135 \underline{\text { Results }}$}

136 Influence of temperature and exposure duration on luciferase induction by $17 \beta-E 2$

137 The stable PELN reporter cell line was first examined for its ability to respond to the reference 138 ER ligand E2 under different assay conditions. Since the functionality of rtER $\alpha$ has been shown 
139 to be sensitive to temperature (Matthews et al., 2002), we first tested effect of E2 at different 140 temperatures. As seen in Fig. 1a, the $\mathrm{EC}_{50}$ value of $\mathrm{E} 2$ was slightly lower at 22 and $25^{\circ} \mathrm{C}(5 \mathrm{nM})$

141 than that observed at $30^{\circ} \mathrm{C}(7 \mathrm{nM})$ or $37^{\circ} \mathrm{C}(12 \mathrm{nM})$. In terms of fold induction, the luciferase

142 signal was also affected by the temperature as luciferase appeared to be less inducible at $22^{\circ} \mathrm{C}$,

143 and to a lesser extent at $25^{\circ} \mathrm{C}$, than at higher temperatures. Hence, by considering both the

144 affinity of E2 to the rtER $\alpha$ and fold induction of luciferase, we chose to perform assays at $25^{\circ} \mathrm{C}$

145 in our experiments. Induction of luciferase was also dependent on exposure duration (Fig. 1b). In

146 our experiments, we thus determined that a $48 \mathrm{~h}$ exposure was appropriate to detect maximal

147 luciferase induction without affecting the $\mathrm{EC}_{50}$ of $\mathrm{E} 2$.

148 Ability of different ER ligands to induce luciferase mediated by rtER $\alpha$ in PELN-rtER cells

149 The figure 2 presents the ability of known ER ligands from different chemicals classes to induce

150 luciferase in PELN-rtER cells. Overall, all examined compounds were able to induce luciferase

151 with various transactivation profiles, in terms of both $\mathrm{EC}_{50}$ values (Table 1) and maximum

152 luciferase response achieved at the highest dose examined (Fig. 2). The natural steroid estrogens

153 E1 and E3 (Fig. 2a), as wells as the synthetic estrogen EE2 (Fig. 2b) behave as total agonists as

154 they elicited maximal transactivation relative to E2. By contrast, partial transactivation curves

155 were observed with the mycoestrogen $\alpha$-ZEA, the phytoestrogen genistein (Fig. 2a) and the

156 pharmaceuticals DES and hexestrol (Fig. 2b), as maximum transactivation was 60-70\%.

157 The industrial chemicals presented also different profiles in their potency and efficacy. The 158 alkylphenols 4-OP and 4-NP (Fig. 2c) were weakly estrogenic in this system, as $45 \%$ of 159 transactivation was achieved at the highest tested concentration $(10 \mu \mathrm{M})$. Bisphenol A behaved 160 as a partial ER agonist. It significantly induced luciferase at a relatively low concentration $(0.3$ $161 \mu \mathrm{M}$ ) but this induction was limited as it reached a maximum response of $35 \%$ relative to E2. 
162 Interestingly, among the different xeno-estrogens tested, benzophenone derivatives most

163 efficiently induced luciferase in PELN-rtER cells (Fig. 2d), especially BP2 and THB that

164 behaved as total agonists for the $\operatorname{rtER} \alpha$, while BP1 induced partial activation of luciferase at 10

$165 \mu \mathrm{M}$ and BP3 was found to be non active.

$166 \quad$ VTG induction by ER ligands in isolated trout hepatocytes

167 In order to compare our results with PELN-rtER with a well recognised in vitro fish system in

168 our laboratory conditions, some chemicals were tested for their ability to induced vitellogenin in

169 isolated rainbow trout hepatocytes (PRTH). As expected, the results summarised in Table 1

170 indicate that all tested compounds induced $\mathrm{Vtg}$ in a dose-response manner allowing $\mathrm{EC}_{50}$

171 determination and were ranked: $\mathrm{EE} 2<\mathrm{E} 2<\alpha-\mathrm{ZEA}<\mathrm{DES}<$ Hexestrol $<$ Genistein $<$ BP $2<4$ -

$172 \mathrm{OP}<\mathrm{THB}<\mathrm{BP} 1$.

\section{Discussion}

174 The stable fish reporter system (PELN-rtER) responded to a diversity of estrogenic compounds

175 with different transactivation potency and efficacy (Fig. 2). In order to determine how this cell

176 model compares with other established in vitro systems, the $\mathrm{EC}_{50}$ and relative estrogenic

177 potencies (REP) were compared to values previously published using two other stable reporter

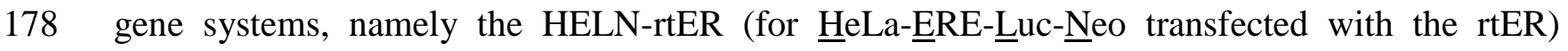

179 (Pillon, 2005, Molina-Molina et al., 2008) and MELN (for MCF-7-ERRE-Luc-ㅌeo) cell lines

180 (Balaguer et al., 1999, Pillon et al., 2005) (Table 1). These two models consist of human cell

181 lines (HeLa and MCF-7 cells) that stably express the luciferase reporter gene under the control of

182 the $\operatorname{rtER} \alpha$ and the human $\mathrm{ER} \alpha$ (hER), respectively. In addition, the ability of chemicals to induce

183 VTG synthesis in primary cultures of rainbow trout hepatocytes (PRTH) has been evaluated and

184 is also reported in Table 1. Overall, the absolute sensitivity to E2 and a majority of the tested 
185 compounds varied among the different assays, and were ranked: PRTH $<$ PELN-rtER $<$ HELN$186 \mathrm{rtER}<\mathrm{MELN}$. The relative estrogenic potency (REP) values allowed ranking of chemicals that 187 was fairly similar in all assays. Nevertheless, Pearson's correlation analyses showed that the fish 188 cell line was better correlated to HELN-rtER $\left(r^{2}=0.91, n=9\right)$ and PRTH $\left(r^{2}=0.90, n=9\right)$ than to $189 \operatorname{MELN}\left(\mathrm{r}^{2}=0.80, \mathrm{n}=9\right)$, suggesting a good adequacy between the different fish-based assays.

190 The higher sensitivity of the human MELN assay can be partly attributed to the known lower 191 binding affinity of E2 for the rtER than for the hER (LeDréan et al., 1995, Matthews et al., 2000, 192 Molina-Molina et al., 2008), due to divergences in the amino acid sequences of the ligand 193 binding domain of these receptors (Pakdel et al., 2000). However, this loss of sensitivity is not 194 systematically found as certain xeno-estrogens, like polychlorobiphenyls (Matthews et al., 2000), 195 some alkylphenols (Olsen et al., 2005) or zearalenone and its derivatives (Le Guevel and Pakdel, 196 2001), have been shown to bind to and activate rtER at equal or lower concentrations than those 197 required to active hER.

198 In the present study, the most significant inter-assay difference concerns the estrogenic activity 199 benzophenone (BP) derivatives, which were almost equipotent in PELN-rtER and HELN-rtER 200 cells, and much less active in the human MELN cells. The good estrogenic potency of BPs 201 towards rtER has been already reported in mammalian cell or yeast-based assays (Kunz et al., 202 2006, Molina-Molina et al., 2008). Here, we report that in a fish cell line, these compounds still 203 have a high estrogenic potency that is in the same order as that of natural ER ligands such as 204 estriol (Table 1). Our results strengthen the recent view that such emerging aquatic pollutants 205 present significant hazard to fish (Kunz et al., 2006) and present further evidence to support the 206 use of appropriate species-related assays to investigate hormonal activity. 
207 In addition, the different metabolic capacities of the cells may also have some influence on the 208 sensitivity of the assays to detect estrogenic activity (Olsen et al., 2005, Bursztyka et al., 2008).

209 HELN-rtER cells are derived from HeLa cells, which are poorly metabolically competent as 210 compared to PLHC-1 cells. The latter have retained significant metabolic capacities including 211 phase I and II biotransformation and efflux transporter proteins (Zaja et al., 2007), which may 212 contribute to reduce the intracellular availability of chemicals for the receptors. In trout 213 hepatocytes, which maintain substantial metabolic capacities in culture, the different tested 214 chemicals were generally active at significantly higher concentrations than in cell lines, although 215 the use of different endpoints (i.e. luciferase activation versus VTG detection) likely influenced 216 the sensitivity of the response. Nevertheless, the observation that $\mathrm{EC}_{50}$ values in PELN-rtER 217 were generally closer to PRTH than to HELN-rtER, could reflect, at least in part, different 218 metabolic capacities in the assays and again a good agreement between the two fish cell models.

219 In summary, the establishment of a reporter cell line that stably expresses rtER-mediated 220 luciferase within a fish hepatoma-derived cell context is reported for the first time. It is proposed 221 that such tool is useful to identify species-specific responses, as shown with benzophenone 222 derivatives. However, the lower sensitivity of the response to a majority of chemicals than in 223 similar human-derived reporter cell lines could lead one to conclude that these cells have 224 limitations for a chemical screening purpose since false negative may occur when assessing 225 weak estrogenic compounds. Nevertheless, correlation with the well-recognised vitellogenin 226 assay in PRTH cells supports the use of PELN-rtER cells to investigate estrogenicity in fish 227 hepatic cell context. Furthermore, the metabolic capacities and in particular the high expression 228 of functional aryl hydrocarbon receptor (AhR) in PLHC-1 cells make the PELN-rtER cell line a 
relevant mechanistic tool to study ER/AhR interaction on receptor transactivation by

230 environmental chemicals in a fish cellular context (Aït-Aïssa et al., in preparation).

\section{Acknowledgements}

232 This work was funded by grant the French ministry of Ecology (P189-AP07) to INERIS. The

233 authors wish to thank anonymous reviewers for helping to improve the quality of the manuscript.

\section{$234 \underline{\text { References }}$}

235

236

237

238

239

240

241

242

243

244

245

246

247

248

249

250

251

252

253

254

255

256

257

258

259

260

261

262

263

264

265

266

267
Ackermann G.E., Brombacher E., Fent K., 2002. Development of a fish reporter gene system for the assessment of estrogenic compounds and sewage treatment plant effluents. Environmental Toxicology and Chemistry 21, 1864-1875.

Balaguer P., Francois F., Comunale F., Fenet H., Boussioux A.M., Pons M., Nicolas J.C., Casellas C., 1999. Reporter cell lines to study the estrogenic effects of xenoestrogens. Science of the Total Environment 233, 47-56.

Brion, F., Nilsen, B.M., Eidem, J.K., Goksoyr, A., Porcher, J.M., 2002. Development and validation of an enzyme-linked immunosorbent assay to measure vitellogenin in the zebrafish (Danio rerio). Environmental Toxicology and Chemistry, 21, 1699-1708.

Bursztyka J., Perdu E., Pettersson K., Pongratz I., Fernández-Cabrera M., Olea N., Debrauwer L., Zalko D., Cravedi J.P., 2008. Biotransformation of genistein and bisphenol A in cell lines used for screening endocrine disruptors. Toxicology in Vitro, 22, 1595-1604.

Hotchkiss A.K., Rider C.V., Blystone C.R., Wilson V.S., Hartig P.C., Ankley G.T., Foster P.M., Gray C.L., Gray L.E., 2008. Fifteen years after "Wingspread" - Environmental endocrine disrupters and human and wildlife health: Where we are today and where we need to go. Toxicological Sciences 105, 235-259.

Kunz P.Y., Galicia H.F., Fent K., 2006. Comparison of in vitro and in vivo estrogenic activity of UV filters in fish. Toxicological Sciences, 90, 349-361

Laville N., Aït-Aïssa S., Gomez E., Casellas C., Porcher J.M., 2004. Effects of human pharmaceuticals on cytotoxicity, EROD activity and ROS production in fish hepatocytes. Toxicology 196, 41-55.

LeDréan Y., Kern L., Pakdel F., Valotaire Y., 1995. Rainbow trout estrogen receptor presents an equal specificity but a differential sensitivity for estrogens than human estrogen receptor. Molecular and Cellular Endocrinology, 109, 27-35.

Le Guevel R., Pakdel F., 2001. Assessment of oestrogenic potency of chemicals used as growth promoter by in-vitro methods. Human Reproduction, 16, 1030-1036.

Matthews J., Celius T., Halgren R., Zacharewski T., 2000. Differential estrogen receptor binding of estrogenic substances: a species comparison. Journal of Steroid Biochemistry and Molecular Biology 74, 223-234.

Matthews J.B., Fertuck K.C., Celius T., Huang Y.W., Fong C.J., Zacharewski T.R., 2002. Ability of structurally diverse natural products and synthetic chemicals to induce gene expression mediated by estrogen receptors from various species. Journal of Steroid Biochemistry and Molecular Biology, 82, 181-194. 
Molina-Molina J-M., Escande A., Pillon A., Gomez E., Pakdel F., Cavaillès V., Olea N., AïtAïssa S., Balaguer P., 2008. Profiling of benzophenone derivatives using fish and human estrogen receptor-specific in vitro bioassays. Toxicology and Applied Pharmacology 232, 384-395.

Navas J.M., Segner H., 2006. Vitellogenin synthesis in primary cultures of fish liver cells as endpoint for in vitro screening of the (anti)estrogenic activity of chemical substances. Aquatic Toxicology 80, 1-22.

Olsen C.M., Meussen-Elholm E.T.M., Hongslo J.K., Stenersen J., Tollefsen K.-E., 2005. Estrogenic effects of environmental chemicals: An interspecies comparison. Comparative Biochemistry and Physiology Part C: Toxicology \& Pharmacology, 141, 267-274.

Pakdel F., Metivier R., Flouriot G., Valotaire Y., 2000. Two estrogen receptor (ER) isoforms with different estrogen dependencies are generated from the trout ER gene. Endocrinology, 141, 571-580.

Pelissero C., Flouriot G., Foucher J.L., Bennetau B., Dunogues J., Legac F., Sumpter J.P., 1993. Vitellogenin Synthesis in Cultured-Hepatocytes - an Invitro Test for the Estrogenic Potency of Chemicals. Journal of Steroid Biochemistry and Molecular Biology 44, 263272.

Pillon A., Boussioux A.M., Escande A., Aït-Aïssa S., Gomez E., Fenet H., Ruff M., Moras D., Vignon F., Duchesne M.J., Casellas C., Nicolas J.C., Balaguer P., 2005. Binding of estrogenic compounds to recombinant estrogen receptor alpha : Application to environmental analysis. Environmental Health Perspectives, 113, 278-284.

Pillon A., 2005. PhD dissertation. University of Montpellier I.

Ryan J.A., Hightower L.E., 1994. Evaluation of Heavy-Metal Ion Toxicity in Fish Cells Using a Combined Stress Protein and Cytotoxicity Assay. Environmental Toxicology and Chemistry 13, 1231-1240.

Smeets J.M.W., van Holsteijn I., Giesy J.P., Seinen W., van den Berg M., 1999. Estrogenic potencies of several environmental pollutants, as determined by vitellogenin induction in a carp hepatocyte assay. Toxicological Sciences 50, 206-213.

Sumpter J.P., 2005. Endocrine disrupters in the aquatic environment: An overview. Acta Hydrochimica et Hydrobiologica, 33, 9-16.

Wilson V.S., Cardon M.C., Gray L.E., Hartig P.C., 2007. Competitive binding comparison of endocrine-disrupting compounds to recombinant androgen receptor from fathead minnow, rainbow trout, and human. Environmental Toxicology and Chemistry 26, 17931802.

Zaja, R., Klobucar, R.S., Smital, T., 2007. Detection and functional characterization of Pgp1 (ABCB1) and MRP3 (ABCC3) efflux transporters in the PLHC-1 fish hepatoma cell line. Aquatic Toxicology, 81, 365-376. 


\section{Figure legends}

Figure 1. (a) Influence of temperature on rtER transactivation (expressed as percentage of maximal luciferase induction) by $17 \beta$-estradiol (E2) in PELN-rtER cells after $24 \mathrm{~h}$ of exposure. (b) Kinetics of luciferase induction (expressed as relative luminescence units or RLU) by $17 \beta$-estradiol in PELN-rtER cells at $25^{\circ} \mathrm{C}$. Values are means \pm SD of triplicates.

Figure 2. Typical dose response curves of luciferase induction (expressed as percentage of luciferase induction by E2 $1 \mu \mathrm{M}$ ) in PELN-rtER by (A) natural (xeno)estrogens: 17 $\beta$ estradiol (E2), estrone (E1), estriol (E3), $\alpha$-zearalanol ( $\alpha$-ZEA), genistein (Gen), (B) pharmaceutical compounds: diethylstilbestrol (DES), hexestrol (Hex), $17 \alpha-$ ethynylestradiol (EE2), (C) alkylphenols: 4-nonylphenol (4-NP), 4-t-octylphenol (4-OP), bisphenol A (BPA) and (D) benzophenone derivates: 2,4-dihydroxybenzophenone (benzophenone 1 or BP1), 2,2',4,4'-tetrahydroxybenzophenone (benzophenone 2 or BP2), 2-hydroxy-4-methoxybenzophenone (benzophenone 3 or BP3), 2,4,4'trihydroxybenzophenone (THB). Cells were exposed for 48 hours at $25^{\circ} \mathrm{C}$; values are means \pm SD of triplicates. 
Table 1: Effective concentrations $\left(\mathrm{EC}_{50}\right)$ and relative estrogenic potencies (REP) of various ER ligands in fish (PELN-rtER, PRTH) and human (HELN-rtER, MELN) cell-based in vitro assays.

$a$ : Except for benzophenone derivatives, HELN-rtER and MELN data were taken from Pillon (2005) and Pillon et al. (2005), respectively. Effect of benzophenone derivatives in MELN, HELN-rtER and PRTH were from Molina-Molina et al. (2008); $b$ : PRTH data were obtained as described in the Materials and Method section.

n.d.: not determined ; n.a.: not active ; -: not applicable; $n$ : number of independent experiments; SEM: standard error of the mean.

\begin{tabular}{|c|c|c|c|c|c|c|c|c|c|c|}
\hline \multirow[b]{2}{*}{ Chemicals } & \multicolumn{4}{|c|}{$\begin{array}{c}\text { PELN-rtER } \\
\text { (fish PLHC-1 cells, } \\
\text { rainbow trout receptor) }\end{array}$} & \multicolumn{2}{|c|}{$\begin{array}{c}\text { HELN-rtER }^{a} \\
\text { (human HeLa cells, } \\
\text { rainbow trout receptor) }\end{array}$} & \multicolumn{2}{|c|}{$\begin{array}{c}\text { MELN }^{a} \\
\text { (human MCF-7 cells, } \\
\text { endogenous receptor) }\end{array}$} & \multicolumn{2}{|c|}{$\begin{array}{c}\text { PRTH }^{b} \\
\text { (isolated rainbow } \\
\text { trout hepatocytes, } \\
\text { endogenous receptor) }\end{array}$} \\
\hline & $\mathrm{EC} 50(\mathrm{nM})$ & SEM & $n$ & REP & $\mathrm{EC} 50(\mathrm{nM})$ & REP & $\mathrm{EC} 50(\mathrm{nM})$ & REP & $\mathrm{EC} 50(\mathrm{nM})$ & REP \\
\hline $17 \beta$-estradiol (E2) & 5.5 & 1.5 & 9 & 1 & 0.25 & 1 & 0.018 & 1 & 22 & 1 \\
\hline Estrone (E1) & 130 & 25 & 3 & 0.04 & 12 & 0.02 & 0.69 & 0.03 & n.d. & - \\
\hline Estriol (E3) & 176 & 58 & 3 & 0.03 & 7.8 & 0.03 & 0.10 & 0.18 & n.d. & - \\
\hline $17 \alpha$-ethynylestradiol (EE2) & 3.6 & 0.4 & 3 & 1.54 & 0.18 & 1.39 & 0.01 & 2.56 & 12 & 1.94 \\
\hline Hexestrol (Hex) & 11 & 5 & 5 & 0.50 & 0.2 & 1.25 & n.d. & - & 206 & 0.11 \\
\hline Diethylstilbestrol (DES) & 23 & 10 & 5 & 0.24 & 0.8 & 0.31 & 0.18 & 0.10 & 130 & 0.18 \\
\hline$\alpha$-zearalanol $(\alpha$-ZEA) & 26 & 14 & 5 & 0.22 & 0.12 & 2.08 & 0.14 & 0.13 & 41 & 0.56 \\
\hline$\alpha$-zearalenol $(\alpha-\mathrm{ZEE})$ & 47 & - & 2 & 0.12 & 0.25 & 1.0 & n.d. & - & n.d. & - \\
\hline$\beta$-zearalenol $(\beta$-ZEA) & 504 & - & 2 & 0.011 & 2.5 & 0.1 & n.d. & - & n.d. & - \\
\hline Genistein (Gen) & 498 & - & 1 & 0.010 & 220 & $1.1 \mathrm{E}-03$ & 27 & $6.7 \mathrm{E}-04$ & 1702 & 0.013 \\
\hline Bisphenol A (BPA) & 352 & 83 & 3 & 0.016 & 400 & $6.3 \mathrm{E}-04$ & 96 & $1.9 \mathrm{E}-04$ & n.d. & - \\
\hline 4-octylphenol (4-OP) & 1938 & - & 2 & $2.9 \mathrm{E}-03$ & 300 & 8.3E-04 & 54 & $3.3 \mathrm{E}-04$ & 36271 & $6.3 \mathrm{E}-04$ \\
\hline 4-nonylphenol (4-NP) & 23028 & - & 1 & $2.4 \mathrm{E}-04$ & 600 & $4.2 \mathrm{E}-04$ & 339 & $5.3 \mathrm{E}-05$ & n.d. & - \\
\hline Benzophenone 1 (BP1) & 3507 & 2515 & 3 & $1.6 \mathrm{E}-03$ & 3477 & 7.2E-05 & 9192 & $1.9 \mathrm{E}-06$ & 100000 & $2.3 \mathrm{E}-04$ \\
\hline Benzophenone 2 (BP2) & 384 & 142 & 4 & 0.014 & 161 & $1.6 \mathrm{E}-03$ & 3284 & $5.5 \mathrm{E}-06$ & 30000 & $7.6 \mathrm{E}-04$ \\
\hline Benzophenone 3 (BP3) & n.a. & - & 3 & - & 18426 & $1.4 \mathrm{E}-05$ & 20315 & $8.8 \mathrm{E}-07$ & n.d. & - \\
\hline $\begin{array}{l}\text { Trihydroxybenzophenone } \\
\text { (THB) }\end{array}$ & 620 & 460 & 3 & 0.009 & 578 & 4.3E-04 & 4012 & $4.5 \mathrm{E}-06$ & 60000 & $3.8 \mathrm{E}-04$ \\
\hline
\end{tabular}



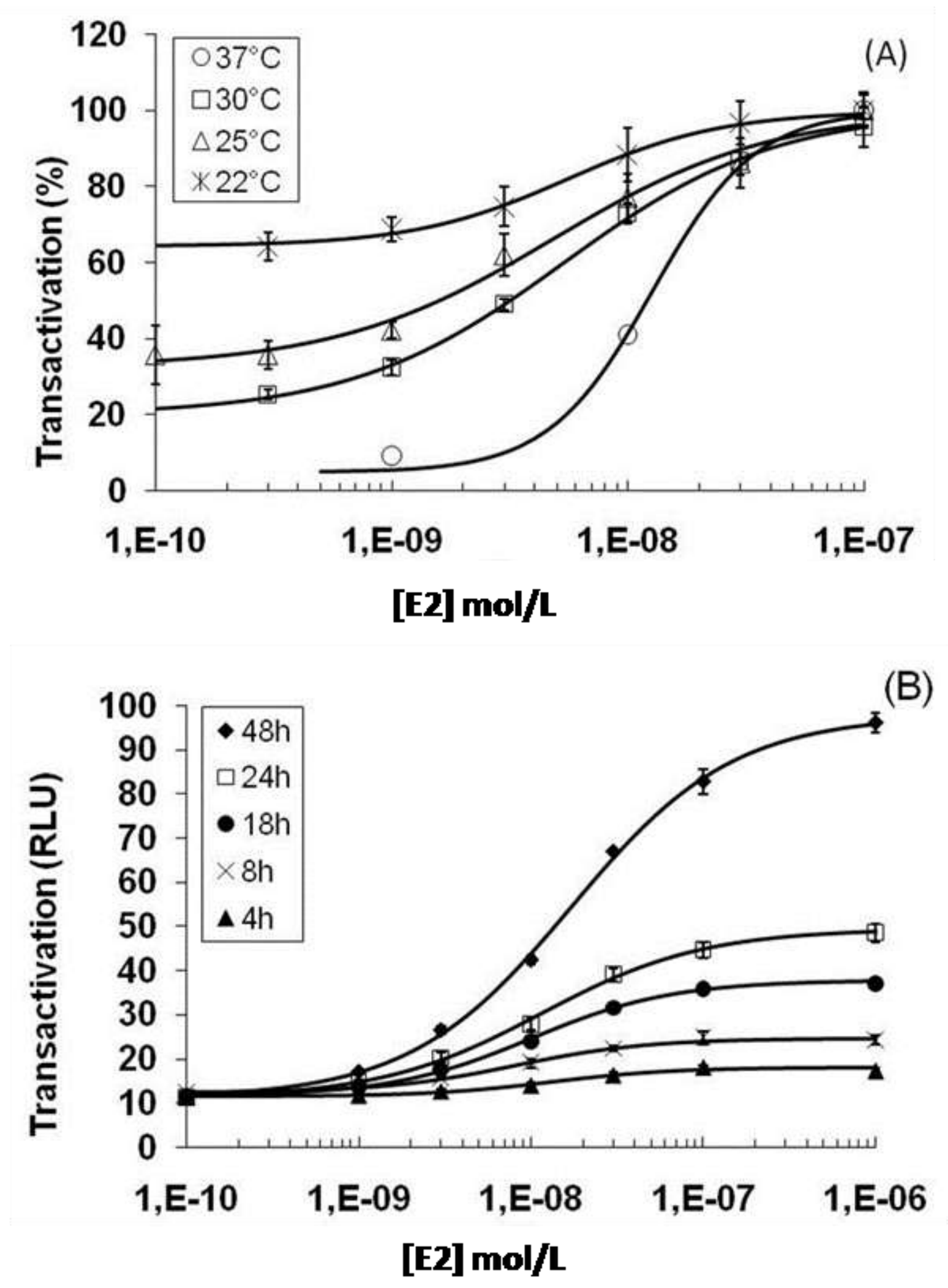

Figure 1 


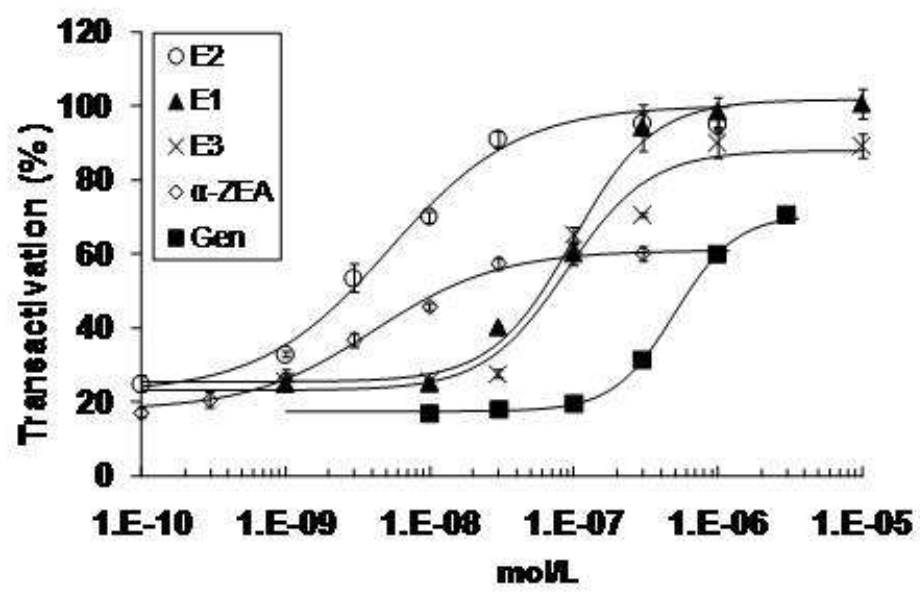

(A)

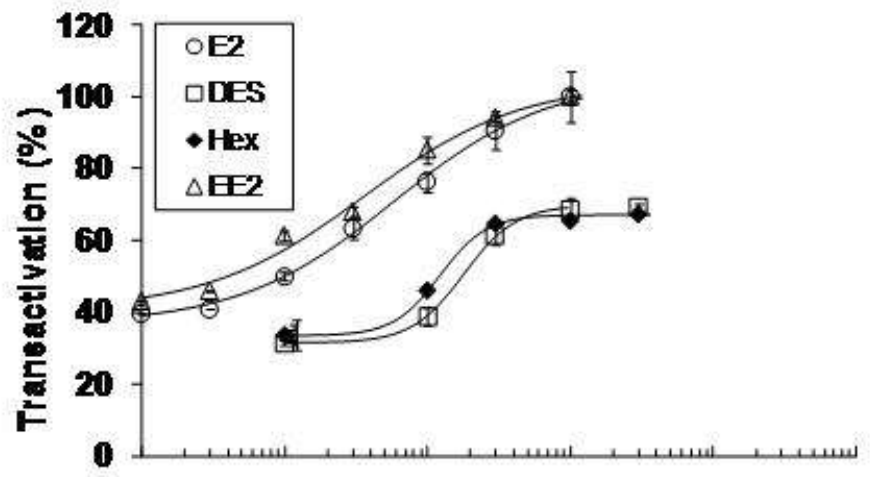

(B)
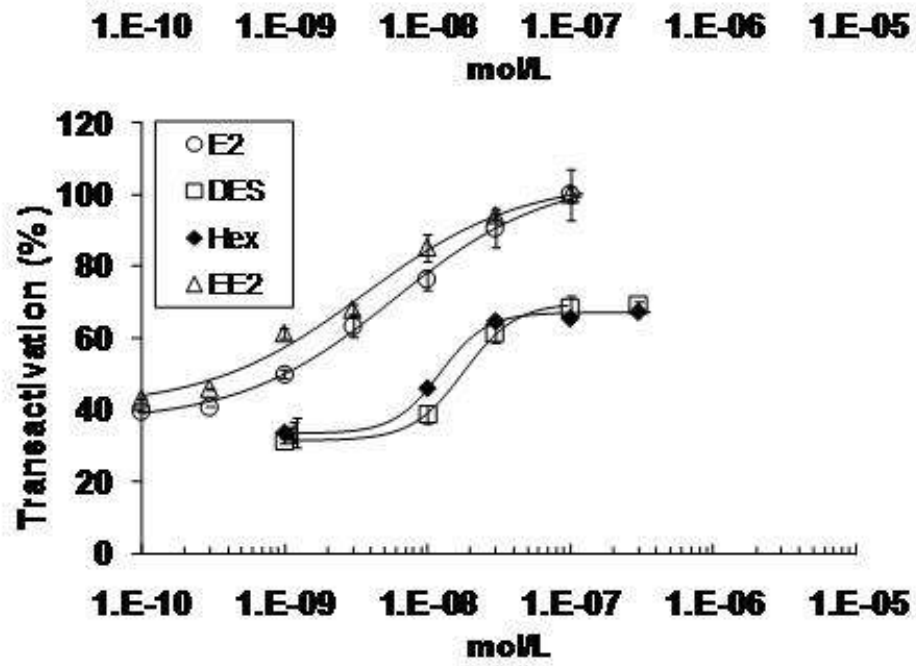

(C)

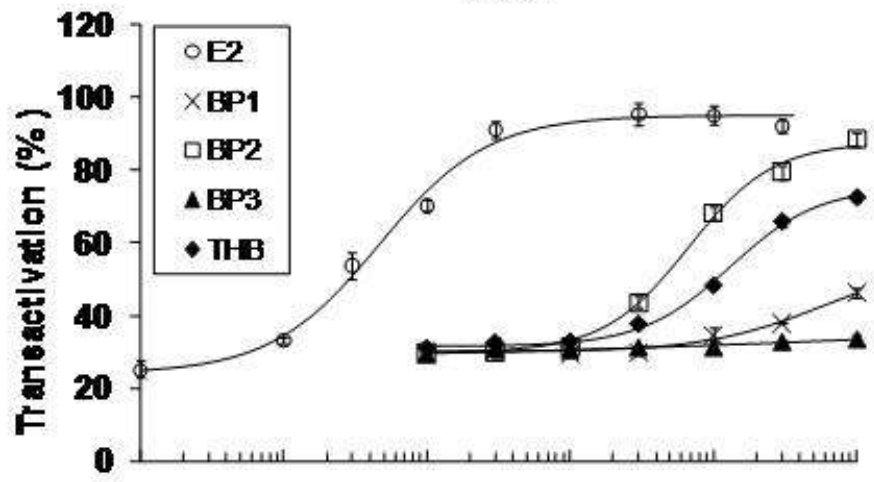

Figure 2

1.E-10 1.E-09 1E-08 1.E-07 1.E-06 1.E-05 moln

(D) 
